Published by Al-Nahrain College of Medicine P-ISSN 1681-6579

E-ISSN 2224-4719

Email: iraqijms@colmed-alnahrain.edu.iq

http://www.colmed-alnahrain.edu.iq

http://www.iraqijms.net

Iraqi JMS 2021; Vol. 19(1)

\title{
The Relevance of Helicobacter pylori Infection to Iron Deficiency Anemia in Duhok City
}

\author{
Adil A. Eissa ${ }^{1}$ FRCPath (Hematology), Saad S. Mirza ${ }^{2}$ FIBMS (Pathology) \\ ${ }^{1}$ Dept. of Pathology, College of Medicine, University of Duhok, Duhok, Iraq, ${ }^{2}$ Duhok Directorate of Health, Duhok Iraq
}

\begin{abstract}
Background Helicobacter pylori (H. pylori) infection had been criticized for many deleterious effects and had been amalgamated to iron deficiency by many authors, frequently based on correlative rather than direct relationship studies and often opposed by others.

Objective To evaluate the role of $H$. pylori infection in the etiology of iron deficiency anemia and to study the impact of the bacterial eradication on the response to iron therapy.

Methods The current study represents an interventional prospective study and involved 52 non-pregnant females with iron deficiency anemia. All patients were tested for the presence of active $H$. pylori infection by stool antigen test and they followed after one month of iron therapy. Patients with positive $H$. pylori infection followed for another month after eradication of $H$. pylori and iron therapy.

Results Fifteen patients (28.85\%) were positive for H. pylori. Hematological and biochemical data were not different among both groups ( $H$. pylori positive and negative) at presentation despite significant better response among $H$. pylori negative individuals. Continuation of iron therapy after eradication of $H$. pylori infection improve the response to therapy significantly.

Conclusion

Keywords

Citation Eradication of $H$. pylori enhances the response to iron therapy significantly. Iron deficiency anemia, H. pylori, iron therapy, eradication

Eissa AA, Mirza SS. The relevance of Helicobacter pylori Infection to iron deficiency anemia in Duhok City. Iraqi JMS. 2021; 19(1): 33-38. doi: 10.22578/IJMS.19.1.5
\end{abstract}

List of abbreviations: $\mathrm{H}$. pylori $=$ Helicobacter pylori, $\mathrm{Hb}=$ Hemoglobin, IDA = Iron deficiency anemia

\section{Introduction}

A nemia is one of the common disorders that disturbs a quarter of the population worldwide, and the higher prevalence is found among preschool-age children and the menstruating females ${ }^{(1-3)}$. As the hemoglobin $\mathrm{Hb}$ ) is the most abundant iron-containing protein in humans, and anemia is a characteristic trait of iron deficiency, thus, iron deficiency anemia (IDA) is considered to be the most common nutrient deficiency and the most common cause of anemia globally ${ }^{(4)}$.
Iron deficiency anemia by many researchers has been related to a longer stay in hospital and reduced life expectancy ${ }^{(5)}$. IDA is a consequence of depletion of the iron stores because of either diminished iron uptake or increased iron loss/use. Body iron homeostasis is mainly through controlling iron entrance to the body rather than controlling its excretion as the body has limited excretion capacity and the gastrointestinal tract is a common site of blood loss and their diseases may cause malabsorption of iron (6).

Some studies showed that Helicobacter pylori ( $H$. pylori) infection is linked to the increased probability of diminished iron storage, and $H$. 
pylori eradication therapy may be beneficial in increasing ferritin levels. Several reported data supported the efficacy of $H$. pylori treatment in moderately to severely anemic patients compared to those with mild anemia. Nonetheless, it should be noted that some studies show negative correlations between $\mathrm{H}$. pylori infection and IDA. It is now recommended that $H$. pylori infection must be tested and treated in patients with unexplained IDA ${ }^{(7)}$.

A conflicting data exist about the relation of $H$. pylori infection to the etiology of IDA and the response of patients to therapy; thus, this study had been initiated to evaluate the role of $H$. pylori in IDA particularly in our locality in Iraq.

\section{Methods}

The current study represents a quasiexperimental interventional prospective study and performed at Azadi Teaching Hospital at Dohuk City, Iraq. Sample collection was done in a period of six months, from September $1^{\text {st }}$, 2019 to February $29^{\text {th }}, 2020$. The study was approved by the Ethical Committee at the Directorate of Health/ Duhok. A total of 52 patients (females), diagnosed as IDA by clinical and laboratory screening were enrolled in this study. All patients were from Duhok Governorate. Any female with age lower than 18 years, gastrointestinal bleeding, pregnancy, lactation, heavy vaginal bleeding, or chronic or significant diseases including chronic inflammatory diseases like rheumatoid arthritis or systemic lupus erythematosus were excluded from the current study.

At first, the process was explained to the patients and informed consent taken from all enrolled individuals. Then $3 \mathrm{ml}$ of peripheral venous blood was taken by a clean and appropriate venipuncture technique from each patient. One milliliter in a sterilized tube containing EDTA, mixed well and subjected for complete blood count using Swelab Hematology Analyzer (Ds Biomed, Sweden) and the remaining 2 milliliters of blood in a gel tube with clot activator for the biochemical test including serum iron, unbound iron-binding capacity, transferrin saturation and serum ferritin using
Cobas 6000 (Roche-Germany). All selected patients were tested also for the presence of active $H$. pylori infection by stool antigen using the One-Step $H$. pylori Antigen Test Kit (Plasmatec laboratory products, UK); infected patients were received oral iron therapy then re-assessed after one month and then received eradication therapy with oral iron therapy and re-assessed after another month, while patients with negative $H$. pylori infection received only oral iron therapy and assessed after one month. After data collection, data were analyzed using statistical package for social sciences (SPSS), version 24.0 (2016). Student t-test was used for comparison of continuous variables, and chisquare or Fisher exact tests were used for comparison of categorical variables. Twosample paired t-test was used to assess the response and the P-value were considered to be significant if it's less than 0.05 .

\section{Results}

Demographic data of all individuals are shown in (Table 1) and it reveals a total of 52 females with IDA had been enrolled in the current study with age ranging from $18-45$ years (median $30 \pm 7.58$ years). From these, 15 (28.85\%) patients had $H$. pylori antigen in the stool and the remaining 37 (71.15\%) were negative for $\mathrm{H}$. pylori antigen.

Their hematological data reveals that the majority had mild $24 / 52$ (46.15\%), to moderate $21 / 52$ (40.39\%) anemia and only $7 / 52$ (13.46\%) had severe anemia. Regarding the severity of anemia among both groups; a majority of patients with $H$. pylori-positive had moderate $6 / 15(40 \%)$ to severe anemia $4 / 15$ (26.67\%) in comparison to $H$. pylori-negative females who had mild $19 / 37$ (51.35\%) to moderate $15 / 37$ $(40.54 \%)$ anemia. No significant difference was seen among both groups $(P=0.09)$. There were no statistically significant differences in the $\mathrm{Hb}$, packed cell volume (PCV), mean corpuscular volume (MCV), mean corpuscular hemoglobin $(\mathrm{MCH})$, iron, total iron binding capacity (TIBC), transferrin saturation (Ts), and ferritin levels between patients with or without $H$. pylori infections with P-value consistently more than 0.05 for the above-examined parameters. 
Table 1. Characteristic of patients with $H$. Pylori positive and negative

\begin{tabular}{lccc}
\hline Parameters & $\begin{array}{c}\text { H. pylori positive (N = 15) } \\
\text { Mean } \pm \text { SD }\end{array}$ & $\begin{array}{c}\text { H. pylori Negative (N = 37) } \\
\text { Mean } \pm \text { SD }\end{array}$ & P value \\
\hline Age (Years) & $32.20 \pm 7.514$ & $28.81 \pm 7.486$ & 0.152 \\
\hline$\leq 20$ (Years) (No.) & 1 & 7 & \\
$21-30$ (Years) (No.) & 6 & 15 & \\
$31-40$ (Years) (No.) & 6 & 12 & \\
$>40$ (Years) (No.) & 2 & 3 & 0.095 \\
\hline Hb (g/dl) & $9.15 \pm 1.19$ & $9.78 \pm 1.158$ & \\
\hline $10-11.9$ (g/dl) (No.) & 5 & 19 & \\
$8.0-9.9$ (g/dl) (No.) & 6 & 15 & 0.070 \\
$<8.0$ (g/dl) (No.) & 4 & $30.92 \pm 2.881$ & 0.247 \\
\hline PCV (\%) & $29.00 \pm 3.41$ & $68.59 \pm 4.597$ & 0.562 \\
MCV (fl) & $67.03 \pm 4.28$ & $21.65 \pm 2.226$ & 0.521 \\
MCH (pg) & $21.15 \pm 2.03$ & $28.30 \pm 6.916$ & 0.539 \\
IRON ( $\mu$ g/dl) & $31.37 \pm 1.79$ & $447.51 \pm 50.390$ & 0.320 \\
TIBC ( $\mu$ g/dl) & $405.07 \pm 62.05$ & $6.30 \pm 1.777$ & 0.118 \\
Transferrin saturation (\%) & $6.95 \pm 2.38$ & $7.14 \pm 3.002$ & \\
Ferritin (ng/ml) & $6.00 \pm 2.21$ & & \\
\hline
\end{tabular}

After one-month oral iron therapy in H. pylorinegative patients and using a two-sample paired t-test, results showed a statistically significant difference in the all examined parameters including $\mathrm{Hb}, \mathrm{PCV}, \mathrm{MCV}, \mathrm{MCH}$, Iron, TIBC, Ts and ferritin (Table 2).

Table 2. Hematological and biochemical parameters difference after Oral iron therapy among H. pylori negative $(\mathrm{N}=37)$

\begin{tabular}{lcccc}
\hline Parameters & Before Treatment & After treatment & $\begin{array}{c}\text { Mean } \\
\text { difference }\end{array}$ & P value \\
\hline $\mathrm{Hb}(\mathrm{g} / \mathrm{dl})$ & $9.78 \pm 1.16$ & $11.97 \pm 1.02$ & 2.20 & $<0.001$ \\
$\mathrm{PCV}(\%)$ & $30.93 \pm 2.82$ & $36.38 \pm 3.08$ & 5.47 & $<0.001$ \\
$\mathrm{MCV}(\mathrm{fl})$ & $68.65 \pm 4.60$ & $78.53 \pm 4.79$ & 9.88 & $<0.001$ \\
$\mathrm{MCH}(\mathrm{pg})$ & $21.69 \pm 2.18$ & $25.82 \pm 1.99$ & 4.13 & $<0.001$ \\
$\mathrm{IRON}(\mu \mathrm{g} / \mathrm{dl})$ & $31.55 \pm 1.59$ & $32.85 \pm 1.38$ & 1.30 & $<0.001$ \\
$\mathrm{TIBC}(\mu \mathrm{g} / \mathrm{dl})$ & $419.22 \pm 51.38$ & $298.78 \pm 59.34$ & 120.43 & $<0.001$ \\
Transferrin saturation $(\%)$ & $6.31 \pm 1.74$ & $18.61 \pm 9.70$ & 12.30 & $<0.001$ \\
Ferritin $(\mathrm{ng} / \mathrm{ml})$ & $7.16 \pm 2.91$ & $17.24 \pm 5.88$ & 10.08 & $<0.001$ \\
\hline
\end{tabular}

The result among $H$. pylori-positive showed lesser changes in all examined parameter, though the statistically significant difference in the all examined parameters including $\mathrm{Hb}, \mathrm{PCV}$, $\mathrm{MCV}, \mathrm{MCH}$, Iron, TIBC, Ts and ferritin (Table 3) and with the eradication of $H$. pylori further significant increment seen per the second months but still lower than $H$. pylori-negative patients (per month), however, after considering the response of the two months of therapy, the result showed highly significant changes with normalization of all parameter including the $\mathrm{S}$. ferritin. 
Table 3. Hematological and biochemical parameters difference among $\mathrm{H}$. pylori positive $(\mathbf{N}=15)$ after first month; second month (after $\boldsymbol{H}$. pylori eradication) and both months together following oral iron therapy

\begin{tabular}{|c|c|c|c|c|c|c|c|c|c|}
\hline \multirow{2}{*}{ Parameters } & \multirow{2}{*}{$\begin{array}{c}\text { Before } \\
\text { Treatment }\end{array}$} & \multicolumn{3}{|c|}{$\begin{array}{l}\text { After treatment } \\
\text { First month }\end{array}$} & \multicolumn{3}{|c|}{$\begin{array}{l}\text { After second month treatment } \\
\text { and } H \text {. Pylori eradication }\end{array}$} & \multicolumn{2}{|c|}{$\begin{array}{l}\text { Two months } \\
\text { taken together }\end{array}$} \\
\hline & & & $\begin{array}{c}\text { Mean } \\
\text { difference }\end{array}$ & $P$ value & & $\begin{array}{c}\text { Mean } \\
\text { difference }\end{array}$ & $P$ value & $\begin{array}{c}\text { Mean } \\
\text { difference }\end{array}$ & $P$ value \\
\hline $\mathrm{Hb}(\mathrm{g} / \mathrm{dl})$ & $\begin{array}{c}9.15 \pm \\
1.19\end{array}$ & $\begin{array}{l}10.88 \pm \\
1.05\end{array}$ & 1.73 & $<0.001$ & $\begin{array}{c}12.53 \pm \\
0.72\end{array}$ & 1.65 & $<0.001$ & 3.38 & $<0.001$ \\
\hline PCV (\%) & $\begin{array}{c}29.00 \pm \\
3.41 \\
\end{array}$ & $\begin{array}{r}33.79 \\
\pm 3.5 .79 \\
\end{array}$ & 4.79 & $<0.001$ & $\begin{array}{c}37.49 \pm \\
2.24\end{array}$ & 3.69 & $<0.001$ & 8.49 & $<0.001$ \\
\hline $\operatorname{MCV}(f l)$ & $\begin{array}{c}67.03 \pm \\
4.28\end{array}$ & $\begin{array}{l}73.49 \pm \\
2.87\end{array}$ & 6.45 & $<0.001$ & $\begin{array}{l}81.14 \pm \\
2.95\end{array}$ & 7.65 & $<0.001$ & 14.11 & $<0.001$ \\
\hline $\mathrm{MCH}(\mathrm{pg})$ & $\begin{array}{l}21.15 \pm \\
2.03\end{array}$ & $\begin{array}{l}23.66 \pm \\
1.05\end{array}$ & 2.51 & $<0.001$ & $\begin{array}{c}27.1 \pm \\
1.26\end{array}$ & 3.44 & $<0.001$ & 5.95 & $<0.001$ \\
\hline IRON ( $\mu \mathrm{g} / \mathrm{dl})$ & $\begin{array}{c}31.37 \pm \\
1.79\end{array}$ & $\begin{array}{c}32.19 \pm \\
1.25\end{array}$ & 0.83 & 0.037 & $\begin{array}{l}75.07 \pm \\
22.63\end{array}$ & 28.13 & $<0.001$ & 44.67 & 0.002 \\
\hline $\operatorname{TIBC}(\mu \mathrm{g} / \mathrm{dl})$ & $\begin{array}{l}405.07 \pm \\
62.05\end{array}$ & $\begin{array}{c}367.67 \pm \\
56.83\end{array}$ & 67.8 & $<0.001$ & $\begin{array}{c}339.0 \pm \\
51.37\end{array}$ & 28.67 & 0.107 & 96.47 & $<0.001$ \\
\hline $\begin{array}{l}\text { Transferrin } \\
\text { saturation (\%) }\end{array}$ & $\begin{array}{c}6.95 \pm \\
2.38\end{array}$ & $\begin{array}{c}13.08 \pm \\
6.05\end{array}$ & 6.14 & $<0.001$ & $\begin{array}{c}21.91 \pm \\
7.28\end{array}$ & 8.83 & $<0.001$ & 14.97 & $<0.001$ \\
\hline $\begin{array}{l}\text { Ferritin } \\
(\mathrm{ng} / \mathrm{ml})\end{array}$ & $\begin{array}{c}6.00 \pm \\
2.21\end{array}$ & $\begin{array}{c}12.25 \pm \\
3.61\end{array}$ & 6.26 & $<0.001$ & $\begin{array}{c}21.76 \pm \\
5.67\end{array}$ & 9.51 & $<0.001$ & 15.76 & $<0.001$ \\
\hline
\end{tabular}

Tables 4 shows the average increment in the $\mathrm{Hb}$, $\mathrm{PCV}, \mathrm{MCV}, \mathrm{MCH}, \mathrm{S}$. Iron and S. ferritin and decrement in the TIBC in both $H$. pylori-negative and $H$. pylori-positive (the first month before $H$. pylori eradication; the second month of iron therapy following eradication of $H$. pylori and two months together) patients and they reveal significant higher response among $H$. pylori- negative patients to iron therapy in the first month in $\mathrm{MCV}, \mathrm{MCH}, \mathrm{S}$. Iron and S. ferritin; significant higher response in the second month in $\mathrm{Hb}, \mathrm{PCV}$, and TIBC; and significantly better response among $\mathrm{H}$. pylori-positive patients in the $\mathrm{Hb}, \mathrm{PCV}, \mathrm{MCV}, \mathrm{MCH}, \mathrm{S}$. ferritin if 2 months taken together.

Table 4. Mean changes in the hematological and biochemical parameters among $\boldsymbol{H}$. pylori negative following iron therapy and $H$. pylori positive (first moth of iron therapy alone); (second month of iron therapy $+\mathrm{H}$. pylori eradication) and (combined first- and secondmonths including $\boldsymbol{H}$. pylori eradication)

\begin{tabular}{|c|c|c|c|c|c|c|c|}
\hline \multirow{2}{*}{ Parameters } & \multirow{2}{*}{$\begin{array}{c}\text { H. pylori } \\
\begin{array}{c}\text { Negative (N }= \\
\text { 37) Mean } \pm \text { SD }\end{array} \\
\begin{array}{c}\text { First month } \\
\text { only }\end{array}\end{array}$} & \multicolumn{6}{|c|}{$\begin{array}{c}H . \text { pylori positive } \\
(\mathrm{N}=15) \text { Mean } \pm \text { SD }\end{array}$} \\
\hline & & $\begin{array}{l}\text { First month } \\
\text { only }\end{array}$ & $\begin{array}{c}P \\
\text { value } \\
(1)\end{array}$ & $\begin{array}{l}\text { Second } \\
\text { month only }\end{array}$ & $\begin{array}{l}\text { P value } \\
\text { (2) }\end{array}$ & $\begin{array}{l}\text { Both months together } \\
+H . \text { pylori eradication }\end{array}$ & $\begin{array}{c}P \\
\text { value } \\
(1+2)\end{array}$ \\
\hline $\mathrm{Hb}(\mathrm{g} / \mathrm{dl})$ & $2.20 \pm 0.78$ & $1.73 \pm 1.24$ & 0.105 & $1.65 \pm 0.69$ & 0.022 & $3.38 \pm 1.32$ & $<0.001$ \\
\hline PCV (\%) & $5.457 \pm 2.78$ & $4.793 \pm 3.87$ & 0.482 & $3.69 \pm 2.19$ & 0.032 & $8.49 \pm 3.00$ & 0.001 \\
\hline MCV (fl) & $9.88 \pm 4.14$ & $6.45 \pm 5.00$ & 0.013 & $7.65 \pm 3.11$ & 0.066 & $14.11 \pm 4.62$ & 0.002 \\
\hline $\mathrm{MCH}(p g)$ & $4.12 \pm 1.42$ & $2.51 \pm 1.81$ & 0.001 & $3.44 \pm 1.35$ & 0.115 & $5.95 \pm 2.43$ & 0.001 \\
\hline IRON ( $\mu \mathrm{g} / \mathrm{dl})$ & $37.41 \pm 25.86$ & $16.53 \pm 16.63$ & 0.005 & $28.13 \pm 20.11$ & 0.219 & $44.67 \pm 17.98$ & 0.326 \\
\hline TIBC ( $\mu \mathrm{g} / \mathrm{dl})$ & $-79.97 \pm 46.20$ & $-67.8 \pm 43.02$ & 0.385 & $\begin{array}{l}-28.67 \pm \\
64.43\end{array}$ & 0.002 & $-96.47 \pm 77.34$ & 0.346 \\
\hline $\begin{array}{l}\text { Transferrin } \\
\text { saturation (\%) }\end{array}$ & $12.30 \pm 9.59$ & $6.14 \pm 5.05$ & 0.02 & $8.83 \pm 5.48$ & 0.195 & $14.97 \pm 5.88$ & 0.322 \\
\hline Ferritin (ng/ml) & $10.08 \pm 4.84$ & $6.26 \pm 4.04$ & 0.009 & $9.51 \pm 4.68$ & 0.697 & $15.76 \pm 6.03$ & $<0.001$ \\
\hline
\end{tabular}




\section{Discussion}

The prevalence of $H$. pylori shows large geographical variations reaching up to $50 \%$ of the population in some developing countries, while the prevalence of $H$. pylori in industrialized countries generally remains under $40 \%$ and is considerably lower in children and adolescents than in adults and elderly people ${ }^{(8)}$. The current study revealed no significant difference between $H$. pylori-positive and negative patients in $\mathrm{Hb}, \mathrm{PCV}, \mathrm{MCV}, \mathrm{MCH}$, S. iron, Ts, TIBC and ferritin; similar results were shown in studies from Turkey and from Iran in which they suggest no correlation between $H$. pylori infection and IDA without assessing treatment response ${ }^{(9,10)}$. Another study from Egypt has shown almost same results but they found significant results after treatment among $H$. pylori-infected patients (11) and their data augment the current results of a significant better response to iron replacement therapy among $H$. pylori-negative individuals, however a study from Alaska found a significant association between low serum ferritin levels and the prevalence of $H$. pylori infection, also a German study found significantly lower levels of hemoglobin in pregnant women suffering from H. pylori infection ${ }^{(12,13)}$. Moreover, an American study found that those who were seropositive for $H$. pylori infection had significantly lower serum ferritin levels compared with seronegative individuals ${ }^{(14)}$. This variability in studies could be due to differences in the geographical and ethnic distribution of patients, age, sample size, sampling procedures, methods of detecting anemia, and methods of detecting H. pylori infection.

Following one month of therapy with iron, the changes in MCV, MCH, S. iron, Ts, and ferritin were significant, while they were nonsignificant in $\mathrm{Hb}, \mathrm{PCV}$, and $\mathrm{TIBC}$ and these changes were concordances with data from Egypt, China and from Israel (11, 15-17).

After $H$. pylori eradication and continuous therapy with oral iron in $\mathrm{H}$. pylori-positive group patients, results showed a statistically significant difference in the $\mathrm{Hb}, \mathrm{PCV}, \mathrm{MCV}, \mathrm{MCH}$, iron, TIBC, Ts and ferritin and with the consideration of the results of the last month after eradication of $H$. pylori, the significant difference still can be observed with the continuation of the iron therapy in all examined parameters $(\mathrm{HB}, \mathrm{PCV}, \mathrm{MCV}, \mathrm{MCH}$, iron and ferritin) except TIBC, this is considered the most reliable evidence for a cause-effect relationship between $H$. pylori infection and IDA. This result corroborated many other studies that showed that the eradication of $H$. pylori shows significant improvement in iron stores with or without hematological response such as from Israel ${ }^{(17,18)}$, Egypt ${ }^{(11)}$, China ${ }^{(15,16)}$, and from India (19), which support our results. However, some other studies show a negative relation between H. pylori eradication and IDA from the USA ${ }^{(20)}$ and Bangladesh (21).

Different mechanisms had been claimed to explain the impaired response to iron therapy among $H$. pylori-positive individuals including mucosal lining penetration by the bacteria to establish infection (8), chronic gastritis with impaired absorption, peptic ulcer with continuous iron loss (22).

In conclusion, hematological and biochemical parameters were not different among both $\mathrm{H}$. pylori-positive and -negative patients. Patients without $H$. pylori infection show significantly better response to iron therapy than patients with $H$. pylori infection and eradication of $H$. pylori improve the response to iron therapy significantly.

\section{Acknowledgement}

Nil.

\section{Author contribution}

Dr. Eissa: Analysis of data and manuscript preparation. Dr. Mirza: data collection.

\section{Conflict of interest}

The authors declare that they have no competing interests in this work.

\section{Funding}

Self-funding.

\section{References}

1. McLean E, Cogswell M, Egli I, et al. Worldwide prevalence of anemia, WHO Vitamin and Mineral Nutrition Information System, 1993-2005. Public Health Nutr. 2009; 12(4): 444-54. doi: $10.1017 /$ S1368980008002401. 
2. Stoltzfus R, Dreyfuss M. Guidelines for the use of iron supplements to prevent and treat iron deficiency anemia. Washington DC, USA: Washington ILSI Press; 1998. p. 1-39.

3. Stoltzfus RJ. Iron deficiency: global prevalence and consequences. Food Nutr Bull. 2003; 24(4 Suppl): S99103. doi: $10.1177 / 15648265030244 S 206$.

4. Miller JL. Iron deficiency anemia: a common and curable disease. Cold Spring Harb Perspect Med. 2013; 3(7): a011866. doi: 10.1101/cshperspect.a011866.

5. Keshav S, Stevens R. New concepts in iron deficiency anaemia. Br J Gen Pract. 2017; 67(654): 10-11. doi: 10.3399/bjgp17X688465.

6. Bayraktar UD, Bayraktar S. Treatment of iron deficiency anemia associated with gastrointestinal tract diseases. World J Gastroenterol. 2010; 16(22): 2720-5. doi: 10.3748/wjg.v16.i22.2720.

7. Franceschi F, Gasbarrini A, Polyzos SA, et al. Extragastric diseases and Helicobacter pylori. Helicobacter. 2015; 20 Suppl 1: 40-6. doi: 10.1111/hel.12256.

8. Brown LM. Helicobacter pylori: epidemiology and routes of transmission. Epidemiol Rev. 2000; 22(2): 283-97. doi: 10.1093/oxfordjournals.epirev.a018040.

9. Saler T, Keşkek ŞÖ, Kırk S, et al. H. pylori may not be associated with iron deficiency anemia in patients with normal gastrointestinal tract endoscopy results. Adv Hematol. 2014; 2014: 375915. doi: $10.1155 / 2014 / 375915$.

10.Zahmatkeshan M, Karimi M, Geramizadeh B, et al. Association between Helicobacter pylori infection and iron deficiency anemia in school-aged iranian children. Indian Pediatr. 2019; 56(5): 387-9.

11. Demerdash DME, Ibrahim $H$, Hassan DM, et al. Helicobacter pylori associated to unexplained or refractory iron deficiency anemia: an Egyptian singlecenter experience. Hematol Transfus Cell Ther. 2018; 40(3): 219-25. doi: 10.1016/j.htct.2018.02.001.

12. Parkinson AJ, Gold BD, Bulkow L, et al. High prevalence of Helicobacter pylori in the Alaska native population and association with low serum ferritin levels in young adults. Clin Diagn Lab Immunol. 2000; 7(6): 885-8. doi: 10.1128/cdli.7.6.885-888.2000.

13. Weyermann M, Rothenbacher D, Gayer L, et al. Role of Helicobacter pylori infection in iron deficiency during pregnancy. Am J Obstet Gynecol. 2005; 192(2): 548-53. doi: 10.1016/j.ajog.2004.08.028.
14. Cardenas VM, Mulla ZD, Ortiz M, et al. Iron deficiency and Helicobacter pylori infection in the United States. Am J Epidemiol. 2006; 163(2): 127-34. doi: 10.1093/aje/kwj018.

15. Yuan W, Yumin L, Kehu Y, et al. Iron deficiency anemia in Helicobacter pylori infection: meta-analysis of randomized controlled trials. Scand J Gastroenterol. 2010; 45(6): 665-76. doi: 10.3109/00365521003663670.

16. Huang X, Qu X, Yan W, et al. Iron deficiency anaemia can be improved after eradication of Helicobacter pylori. Postgrad Med J. 2010; 86(1015): 272-8. doi: 10.1136/pgmj.2009.089987.

17. Hudak L, Jaraisy A, Haj S, et al. An updated systematic review and meta-analysis on the association between Helicobacter pylori infection and iron deficiency anemia. Helicobacter. 2017; 22(1). doi: 10.1111/hel.12330.

18. Hershko C, lanculovich $M$, Souroujon $M$. A hematologist's view of unexplained iron deficiency anemia in males: impact of Helicobacter pylori eradication. Blood Cells Mol Dis. 2007; 38(1): 45-53. doi: 10.1016/j.bcmd.2006.09.006.

19. Malik R, Guleria K, Kaur I, et al. Effect of Helicobacter pylori eradication therapy in iron deficiency anaemia of pregnancy - a pilot study. Indian J Med Res. 2011; 134(2): 224-31.

20. Tseng DS, Li D, Cholleti SM, et al. Effect of Helicobacter pylori treatment on unexplained iron deficiency anemia. Perm J. 2019; 23: 18-195. doi: 10.7812/TPP/18-195.

21. Sarker SA, Mahmud H, Davidsson L, et al. Causal relationship of Helicobacter pylori with iron-deficiency anemia or failure of iron supplementation in children. Gastroenterology. 2008; 135(5): 1534-42. doi: 10.1053/j.gastro.2008.07.030.

22. Marshall BJ, Warren JR. Unidentified curved bacilli in the stomach of patients with gastritis and peptic ulceration. Lancet. 1984; 1(8390): 1311-5. doi: 10.1016/s0140-6736(84)91816-6.

\author{
Correspondence to Dr. Adil A. Eissa \\ E-mail: adilkhr77@uod.ac \\ Received Jul. $7^{\text {th }} 2020$ \\ Accepted Jan. 24 2021
}

